http://dx.doi.org/10.15762/ZH.2015.35

EWA BARYLEWSKA-SZYMAŃSKA

(Instytut Historii PAN)

\title{
„RZECZY GDAŃSKIE” W DOMACH MIESZCZAN WARSZAWSKICH W DRUGIEJ POŁOWIE XVIII WIEKU
}

Słowa kluczowe: meble, naczynia, fajans, cyna, tkaniny, Gdańsk, mieszczaństwo, Warszawa, kultura materialna

W badaniach nad polskim rzemiosłem i kulturą materialną od dawna wskazywano na Gdańsk jako miejsce nabywania zarówno importowanych, zazwyczaj luksusowych towarów, jak i przedmiotów wykonanych w miejscowych warsztatach rzemieślniczych. Różnorodność zamówień kierowanych do gdańskich rzemieślników była duża: od luksusowych mebli i sreber, przez instrumenty muzyczne, wyroby zegarmistrzowskie, pojazdy, po proste utensylia kuchenne, tekstylne obicia ścian czy też bieliznę stołową. Nawet miotły wykonywane nad Motławą cieszyły się popytem. Na gdańskim rynku w XVIII stuleciu zaopatrywała się polska szlachta i duchowieństwo, zakupy zlecali również magnaci.

Sposobność po temu nadarzała się podczas dłuższych pobytów w mieście ${ }^{1}$. Naturalną okazją były również pobyty związane z dostarczaniem do Gdańska płodów rolnych i leśnych spławianych Wisłą. W tym miejscu można jedynie zasygnalizować to niezwykle interesujące zjawisko. Niejednokrotnie przywoływano w opracowaniach postać kasztelana wiskiego i podczaszego województwa podlaskiego Jacka Rostworowskiego. Jego „Reiestr sprawunków do Gdańska” obejmujący całe dziesięciolecie powstał w latach 1747-1757. Oprócz produktów spożywczych co roku na liście „sprawunków” znajdowały się również gdańskie wyroby, które zamawiano, odbierano bądź też dawano do naprawy w warsztatach rzemieślniczych, m.in. konwisarskim, złotniczym, tkackim, stolarskim. W Gdańsku szlachcic zaopatrywał siebie i rodzinę w kufry i stoliki do gier, drobną, srebrną galanterię stołową czy też w naczynia cynowe, miedziane i mosiężne oraz w sprzęty kuchenne.

${ }^{1}$ Na temat przebywającej w Gdańsku szlachty i magnaterii zob. m.in. Teresa ZıELIŃsKa, Przyczynek do sprawy własności szlacheckiej w Gdańsku XVIII stulecia, [in:] Ludzie - kontakty - kultura XVI-XVIII w. Prace ofiarowane Profesor Marii Boguckiej, red. Jerzy KoweCKI, Janusz TAzBIR, Warszawa 1997, s. 101-110; Ewa Barylewska-Szymańska, Domy szlachty w osiemnastowiecznym Gdańsku, [in:] Život pražských paláců. Šlechtické paláce jako součást městského organismu od středověku na práh moderní doby, sestavili Olga Fejtová, Václav Ledvinka, Jiří PešEK (Documenta Pragensia, 28), Praha 2009, s. 505-533; il. CLXXXI-CXC. 
Nabywano dla niego bieliznę stołową oraz tkaniny przeznaczone do wnętrz domu (obiciowe) i pasmanterię 2 .

Znane są również zakupy zlecane przez innego z przedstawicieli stanu szlacheckiego, kasztelana warszawskiego Pawła Benoego. Kupował on w Gdańsku m.in. kufry, skrzynie na broń, krzesła (w tym również wybijane złoconym kurdybanem), wyroby ślusarskie i kowalskie, utensylia kuchenne (np. młynek do kawy), a nawet zupełnie prozaiczne „miotły gdańskie”. Także skrzypce z dodatkowymi strunami przechowywane w specjalnym „puzdrze”.

Gdańskie wyroby zamawiali również duchowni. Wśród nich na szczególną uwagę zasługuje biskup Adam Stanisław Grabowski ${ }^{4}$ Na jego zlecenie gdański złotnik Michael Diedrich zrobił srebrną zastawę stołową. Przebywając niemal nieprzerwanie nad Motławą od października 1737 r. do sierpnia 1738 r., biskup zamówił kolejne drobne już wyroby złotnicze - naczynia liturgiczne i naczynia stołowe. Do stolarzy skierował zlecenie na meble - stół na 24 osoby oraz tuzin stołków. Kazał też należące do niego sprzęty naprawiać i tapicerować. W Gdańsku kupił również dwie nowe karety.

Nawet w dobytku mniej zasobnego duchowieństwa znajdowały się gdańskie wyroby - srebrna i cynowa zastawa stołowa, fajanse, a także pojedyncze meble 5 .

Kolejne przykłady osób zaopatrujących się w Gdańsku można znaleźć wśród polskich magnatów. Na zlecenie hetmana Jana Klemensa Branickiego nad Motławą nabywano różnorodne wyroby. Były wśród nich marmurowe płyty posadzkowe, szkło do szklenia okien, zwierciadła i tkaniny na potrzeby wystroju pałacu w Białymstoku. Niektóre meble do wyposażenia zamówił kilkakrotnie w Gdańsku. Naturalnie uzupełniano tu także zastawę stołową: srebra, porcelanę, szkło stołowe. Nad Motławą hetman zaopatrywał się także w sprzęty kuchenne. Na marginesie można też wspomnieć o zakupach spożywczych, winach, wódkach, przyprawach, artykułach higienicznych i kosmetycznych. Na listach sprawunków czynionych na

${ }^{2}$ Naturalnie nie pomijano wyrobów zagranicznych, na zlecenie Rostworowskiego kupowano naczynia ceramiczne - porcelanowe i fajansowe - zob. Stefan Marian Rostworowski, Co szlachcic polski w XVIII wieku kupował w Gdańsku, Rocznik Gdański (dalej cyt. RG), t. 7/8: 1933-1934, s. 348-384; idem, Rachunki kupców gdańskich $z$ lat 1732-1768. Materiały historyczne $z$ archiwum rodzinnego, ibid., t. 9/10: 1935-1936, s. 461-485 (lista sprawunków, s. 462-467). Zob. również Ewa BARYLEWSKA-SZYMAŃsKa, Od piwnic po strych. Wnętrza domów gdańskich drugiej połowy XVIII wieku, Warszawa-Gdańsk 2015 - zwłaszcza rozdział: Rynek wyposażenia domowego w osiemnastowiecznym Gdańsku, s. 231-241.

${ }^{3}$ Andrzej Romanow, Materiały do dziejów spławu na Sanie i Wiśle w XVIII wieku. „Fryor gdański” Pawła Benoego, kasztelana warszawskiego, RG, t. 43: 1983, z. 1, s. 167-212.

${ }^{4}$ Ponoszone wówczas wydatki zostały spisane przez jego dworzanina Aleksego Husarzewskiego - zob. na ten temat m.in. Jerzy Dygda£A, Wydatki biskupa Adama Stanisława Grabowskiego podczas pobytu w Gdańsku w latach 1737-1738, [in:] Ludzie - kontakty - kultura XVI-XVIII w., s. 111-117. Na temat biskupa A.S. Grabowskiego zob. idem, Adam Stanisław Grabowski (1698-1766). Biskup, polityk, mecenas, Olsztyn 1994.

${ }^{5}$ Dariusz GŁówKa, Rzeczy gdańskie w ruchomościach duchowieństwa katolickiego Rzeczypospolitej w XVII-XVIII w., Kwartalnik Historii Kultury Materialnej (dalej cyt. KHKM), R. 49: 2001, nr 1-2, s. $95-104$. 
przestrzeni 40 lat nie brakowało także narzędzi rolniczych, sprzętu do polowań, ołowiu do szklenia szyb, farb dla malarzy portrecistów, a nawet drzewek owocowych i ozdobnych! Nie obyło się też bez wszelkich mioteł, szczotek do froterowania, omiatania czy do „chędożenia” sreber6

Także hetman wielki koronny Adam Mikołaj Sieniawski „we wszystko zaopatrywał się w Gdańsku" . Zlecał on swoim faktorom zarówno zakup artykułów spożywczych (w tym przypraw i używek), chemikaliów na potrzeby produkcyjne, jak i tkanin na stroje czy też wyrobów na wyposażenie domu, chociaż te ostatnie nie były liczne. Można wśród nich wskazać pojedyncze meble (np. „złocone krzesła”), szkatuły, lustra, konwie metalowe, talerze i dzbany, zamki drzwiowe, a nawet gipsowe figury. Lista obejmowała również zakup barometru i termometru. Wiadomo też, że dostarczał on do gdańskich warsztatów tkackich przędzę, z której wykonywano płótna na obrusy i serwety.

Dużo ambitniejsze zamówienie ulokował w mieście wojewoda malborski Michał Czapski. Skierował je do czołowego gdańskiego złotnika - Johanna Gottfrieda Schlaubitza ${ }^{8}$. W dwóch etapach w latach 1757 i 1759 oraz 1764-1768 zamówił kilkaset elementów zastawy stołowej, która złożyła się na okazały, reprezentacyjny serwis9.

Również stołeczne mieszczaństwo było odbiorcą wyrobów gdańskich, choć skala zjawiska nie jest do końca dostatecznie rozpoznana. Autor artykułu opublikowanego na łamach dodatku „Kuriera Warszawskiego” z 2 XI 1823 r. napisał na temat kondycji warszawskiego rzemiosła meblarskiego następujące uwagi: „przed kilkudziesięciu laty sprowadzano ze Gdańska stoły wysadzane, zegary szafiaste, krzesła skórą wyzłacaną obite"10. Sugerowałoby to znaczniejszą skalę sprowadzania umeblowania znad Motławy. Jednak w drugiej połowie XVIII w. poza kuframi nie ma nazbyt wielu gdańskich mebli w domach stołecznego mieszczaństwa, a i inne sprzęty o tej proweniencji, wnosząc na podstawie zawartych w inwentarzach mienia opisach, nie występują na dużą skalę.

${ }^{6}$ Elżbieta KowecкA, Dwór „najrzadniejszego w Polszcze magnata”, Warszawa 1991, s. 64-66, 87, 111, 113-114, 129; eadem, Obraz rynku towarów luksusowych $w$ Warszawie połowy XVIII wieku w korespondencji magnackiej, KHKM, R. 40: 1992, nr 1, s. 44.

${ }^{7}$ Józef BurszTa, Handel magnacki i kupiectwo między Sieniawa nad Sanem a Gdańskiem od końca XVII do połowy XVIII wieku, Roczniki Dziejów Społecznych i Gospodarczych, t. 16: 1954, s. 174-223, zwłaszcza s. 206-216.

${ }^{8} \mathrm{Na}$ temat J.G. Schlaubitza zob. Michał Gradowski, Agnieszka Kasprzak-Miler, Złotnicy na ziemiach pótnocnej Polski, cz. 1: Województwo pomorskie, kujawsko-pomorskie i warmińsko-mazurskie, Warszawa 2002, s. 132-133; Jacek KRIEGSEISEN, Słownik złotników gdańskich czynnych w latach 1700-1816, [in:] „...tyżek srebrnych dwa tuziny”. Srebra domowe w Gdańsku 1700-1816. Katalog wystawy w Domu Uphagena, lipiec-listopad 2007, red. Jacek Kriegseisen, Ewa Barylewska-SzymańSKA, współpraca Wojciech SzYMaŃsKi, Gdańsk 2007, s. 184.

${ }^{9}$ Serwis składał się z około 526 elementów o łącznej wadze około 400 kg, zob. Jerzy ŻMudzińSKI, „Robota kredensowa” gdańskiego złotnika Jana Gotfryda Schlaubitza dla wojewody malborskiego Michała Czapskiego w świetle kontraktów i rachunków z lat 1757-1768, [in:] „...łyżek srebrnych dwa tuziny". Srebra domowe w Gdańsku, s. 87-101.

${ }^{10}$ Cytat za: Bożenna Maszkowska, Z dziejów polskiego meblarstwa okresu Oświecenia (Studia z dziejów polskiego rzemiosła artystycznego, t. 1), Wrocław 1956, s. 5-6. 
Zagadnienie „rzeczy gdańskich” w domach warszawskich mieszczan było $\mathrm{w}$ badaniach podejmowane, jednak czyniono to na marginesie innych tematów. Kwestie te poruszyły choćby Bożenna Maszkowska, omawiając osiemnastowieczne meblarstwo ${ }^{11}$, czy Hanna Szwankowska, analizując mieszczańskie wnętrza domów stołecznych w XVIII stuleciu ${ }^{12}$. Wydaje się jednak, że zachowane w warszawskim Archiwum Głównym Akt Dawnych inwentarze stołecznych mieszczan $\mathrm{z}$ drugiej połowy XVIII w. uprawniają do przyjrzenia się tym kwestiom ponownie. Baza źródłowa, jaka stoi do dyspozycji badaczy zasobów domów warszawskich, to kilkaset inwentarzy zgromadzonych $\mathrm{w}$ kilku zespołach ${ }^{13}$. Źródła te są więc dalece skromniejsze niż materiały źródłowe dla analogicznego okresu zachowane w Gdańsku ${ }^{14}$. Na potrzeby artykułu wykorzystałam zespoły ksiąg miejskich: Stara Warszawa oraz Warszawa-Ekonomiczne, ograniczając kwerendę do okresu drugiej połowy XVIII w.

Na początku trzeba poczynić pewne ustalenia. W warszawskich spisach pośmiertnych mienia, podobnie zresztą jak to było w tego typu dokumentach $\mathrm{w}$ innych miastach, proweniencję wyrobów podawano bardzo rzadko. Najczęściej wymieniano poszczególne przedmioty, grupując je kategoriami, niekiedy zapis był uzupełniany oszczędnym opisem charakteryzującym dany przedmiot, często $\mathrm{w}$ spisach inwentarzowych zamieszczano także wycenę $e^{15}$. Sprzęty domowe - meble, naczynia i sprzęty kuchenne, metalowa zastawa stołowa, zegary - nie były zazwyczaj bliżej opisywane. Można założyć, że znacząca ich część powstała na miejscu i została wykonana przez stołecznych rzemieślników ${ }^{16}$, zwłaszcza że w drugiej połowie stulecia warszawskie rzemiosło stało na dobrym poziomie.

${ }^{11}$ Ibid., s. 47-48.

${ }^{12}$ Hanna SzwankowsKa, Wnętrza warszawskich domów w XVIII wieku, KHKM, R. 8: 1960, nr 3, s. 327.

${ }^{13}$ Źródła te omówiła H. Szwankowska, zob. ibid., s. 313-314.

${ }^{14}$ W ocenie prof. dr. hab. Edmunda Kizika w gdańskim Archiwum Państwowym znajduje się kilkanaście tysięcy inwentarzy mienia.

${ }^{15}$ Literatura, w której zostały omówione zasady sporządzania inwentarzy, a także ich przydatność do badań nad kulturą materialną, jest szeroka. W tym miejscu można jedynie wymienić kilka nowszych publikacji: Andrzej Klonder, Wszystka spuścizna w Bogu spoczywającego. Majątek ruchomy zwykłych mieszkańców Elblaga i Gdańska w XVII wieku (Studia i Materiały z Historii Kultury Materialnej, t. 68), Warszawa 2000, s. 7-27. W 2002 r. zorganizowana została konferencja zatytułowana „Inwentarz jest urzędne popisanie rzeczy”. Rejestry majątku ruchomego mieszkańców Polski doby nowożytnej. Bilans i perspektywy. Materiały z konferencji ukazały się drukiem na łamach czasopisma Kwartalnik Historii Kultury Materialnej (R. 51: 2003, nr 2 oraz R. 52: 2004, nr 1). Wśród opublikowanych tekstów ukazał się artykuł Dariusza Główki i Andrzeja Klondera podsumowujący wcześniejsze dokonania (Dariusz GŁówKA, Andrzej KLONDER, Inwentarze mienia w badaniach kultury Europy od średniowiecza po nowożytność, KHKM, R. 51: 2003, nr 2, s. 157-176). Zob. także: Edmund Kızıк, Bilans na koniec życia. Gdańskie inwentarze pośmiertne z drugiej połowy XVII i z XVIII wieku (w przygotowaniu do druku), tam zebrana wcześniejsza europejska i polska literatura przedmiotu.

${ }^{16}$ Do nieczęsto spotykanych przykładów należy wymienienie nazwiska zegarmistrza, twórcy zegara opisanego w następujący sposób: „stary, szafiasty z krótkim perpendykułem, który cały tydzień za jednym nakręceniem idzie, godziny bije, z imieniem H. Angier a Varsovie" - Archiwum Główne Akt Dawnych (dalej cyt. AGAD), Księgi miejskie Starej Warszawy, nr 327, k. 441 (1785 r.). Niestety, 
Taksatorzy, spisując wyroby, jedynie w nielicznych przypadkach wskazywali miejsce ich pochodzenia. Zazwyczaj w ten sposób charakteryzowano obce wyroby ceramiczne. W użyciu w domach warszawskich było sporo naczyń „holenderskich”, zarówno fajansu stołowego, jak i ozdobnych waz służących do dekoracji wnętrz ${ }^{17}$.

Porcelana była $\mathrm{w}$ tym czasie nadal jeszcze niezbyt powszechna $\mathrm{w}$ środowisku mieszczańskim. Niektóre wyroby określano jako „saskie” ${ }^{18}$, więc pochodzące z manufaktury miśnieńskiej ${ }^{19}$. Od lat trzydziestych XVIII w. w Warszawie działał magazyn wyrobów z Miśni ${ }^{20}$, co zwiększyło dostępność tych przedmiotów na miejscowym rynku. Do warszawskich gospodarstw domowych trafiały w końcu wieku XVIII także wyroby z Królewskiej Manufaktury w Berlinie ${ }^{21}$, ale były one zupełnie nieliczne. Rzadko w użyciu była też porcelana dalekowschodnia ${ }^{22}$.

Niekiedy wskazywano także proweniencję wyrobów złotniczych - sreber domowych ${ }^{23}$ czy wyrobów konwisarskich ${ }^{24}$. Do zupełnie odosobnionych przykładów

nie udało się odnaleźć żadnych informacji o tym zegarmistrzu; za pomoc dziękuję kustoszowi Stefanowi S. Mieleszkiewiczowi z Muzeum Narodowego w Warszawie, zajmującemu się zabytkowymi zegarami i meblami.

${ }^{17}$ Np. „3 wazy z przykrywadłem holender[skie]” - ibid., nr 320, k. 62 (1758 r.). Z kolei w domu małżonków Andrychowiczów poza wazami w użyciu były też różnego rodzaju naczynia stołowe ibid, nr 325, k. 12 v-13 (1780 r.). Podobnie u Doroty Elżbiety Krebsowej, która miała talerze, półmiski „w kwiaty” i mniejszy „przeplatany” oraz „imbryczek do herbaty” - ibid., k. 120 v-121 (1782 r.). W innym domu korzystano z tuzina „hollender[skich] filiżanków” oraz dwóch talerzy - ibid., Księgi miejskie Warszawa-Ekonomiczne, nr 1223/308, k. 810 (1757 r.).

${ }^{18}$ Np. ibid., Księgi miejskie Warszawa-Ekonomiczne, nr 1223/316, k. 852 (1766 r.); nr 1223/308, k. 810 (1757 r.); Księgi miejskie Starej Warszawy, nr 321, k. 9v (1763 r.); nr 325, k. 12v (1780 r.); k. 111 (1782 r.); k. 120v (1782 r.).

${ }^{19}$ Natomiast w gdańskich inwentarzach mienia częściej używano określenia „drezdeńska porcelana” („Dresdner Porzellan”), zob. np. Archiwum Państwowe w Gdańsku (dalej cyt. APG), Akta urzędu prezydującego burmistrza, sygn. 300, 1/172, s. 506 (1790 r.); Urząd Sędziego, sygn. 300, 6/174, s. 116 (1785 r.); sygn. 300, 6/175, s. 52 (1785 r.). Rzadziej „porcelana saksońska” („sächsisch[es] Porcelain”), zob. np. ibid., Urząd Sędziego, sygn. 300, 6/163, s. 320 (1774 r.); sygn. 300, 6/165, s. 416 (1776 r.).

${ }^{20}$ Elżbieta Kowecka, Obraz rynku towarów luksusowych $w$ Warszawie, s. 43. Na temat recepcji miśnieńskiej porcelany w Polsce zob. też interesujące artykuły: Jakub Sıтo, Porcelana miśnieńska $w$ Warszawie. Z badań nad inwentarzami rezydencji magnaterii warszawskiej XVIII w., Studia Wilanowskie, t. 20: 2012, s. 114-120; Ulrich PIETsch, Uwagi do projektu badawczego „Miśnieńska porcelana w XVIII wieku dla szlachty i arystokracji w Polsce”, ibid., s. 12-15.

${ }^{21}, 5$ i $1 \frac{1}{2}$ tuzina filiżanek berlińskich” znajdowało się w sklepie, natomiast „maselniczka berlińska" była w użyciu domowym - AGAD, Księgi miejskie Starej Warszawy, nr 325, k. 101v, 111 (1782 r.).

${ }^{22}$ Np. „4 talerze chińskiej porcelany” - ibid., Księgi miejskie Starej Warszawy, nr 321, k. 167 (1770 r.). W innym domostwie chińskich wyrobów było nieco więcej: filiżanki, w tym do czekolady, oraz „1 czarka” - ibid., nr 325, k. 12v (1780 r.).

${ }^{23}$ Np. „1 balsamka Auspurska” - ibid., nr 324, k. 12 (1779 r.); czy też augsburska taca - ibid., Księgi miejskie Warszawa-Ekonomiczne, nr 1223/342, k. 1069 (około 1750 r.).

${ }^{24}$ Np. „misa rantowa, cyna ang[ielska]” - ibid., Księgi miejskie Starej Warszawy, nr 324, k. 13 (1779 r.). W domu małżonków Andrychowiczów wśród naczyń cynowych wyróżnione zostały odrębne kategorie „cyna angielska” i „cyna królewska” - ibid., nr 325, k. 4v-5v (1780 r.). Podobnie postąpili spisujący również u Piotra Koytkowskiego - ibid., nr 325, k. 106 (1782 r.). 
należy podanie pochodzenia innych naczyń metalowych - miedzianych „2 imbryczków tureckich" ${ }^{25}$, ponieważ wyroby miedziane i mosiężne oraz z blachy stalowej nie były określane pod względem proweniencji.

$\mathrm{Na}$ wyposażeniu domów stołecznych znajdowały się czasem również „angielskie”26 albo rzadziej „wiedeńskie”27 zegary. Wyjątkowo rzadko spisujący dobytek podawali pochodzenie mebli. W użyciu były np. „saskie komody”28, „stolik nocny francuskiej roboty wykładany drewnem różanym” ${ }^{29}$, „krakowskie krzesła” ${ }^{\prime 30}$ czy też kanapa pochodząca $\mathrm{z}$ tego samego miasta ${ }^{31}$.

Niezbyt liczne w mieszczańskich domach warszawskich były również „rzeczy gdańskie", na tych właśnie przedmiotach skupię uwagę. Zgrupowałam je w kilku kategoriach: mebli, wyrobów fajansowych i cynowych oraz tkanin.

\section{SZAFY}

Przegląd sprzętów gdańskich rozpocznę od mebli, wśród nich niewątpliwie na uwagę zasługują szafy, choć w przebadanych przeze mnie dobytkach domowych było ich zaledwie kilka. Wnosząc $\mathrm{z}$ bardzo uproszczonego opisu, były to często meble zapewne o barokowym rodowodzie (tradycja tego typu sprzętów utrzymała się zresztą nad Motławą stosunkowo długo) ${ }^{32}$ (il. 1). Szafy te należały do osób zamożnych. W domostwie małżonków Andrychowiczów (Antoni Kazimierz był rajcą Starej Warszawy) spisujący dobytek odnotowali: „szafa wielka, gdańska dembowa, polerowana, wierzchem snycerską robotą, na gałkach, z szufladami”33. To typowa sieniowa szafa gdańska wsparta na kulistych nogach, z szufladą w partii cokołu i drzwiami zdobionymi dekoracją snycerską, zapewne z przerwanym gzymsem i umieszczoną w tym miejscu dekoracją rzeźbiarską. Warto wspomnieć, że był to najkosztowniejszy mebel w ich dobytku.

${ }^{25}$ Ibid., Księgi miejskie Warszawa-Ekonomiczne, nr 1223/342, k. 1070 (około 1750 r.).

${ }^{26}$ Dwa zegary „angielskie tygodniowe” (tj. nakręcane co siedem dni) - ibid., Księgi miejskie Starej Warszawy, nr 324, k. 16 (1779 r.). Kolejny angielski zegar szafowy „na tydzień raz nakręcający się, godziny bijący z excytarzem y repetycją" - ibid., nr 323, k. 56v (1773 r.). Zbliżony zegar tej samej proweniencji, który dodatkowo „dni miesiąca okazuje” - ibid., nr 327, k. 441 (1785 r.). Natomiast w przypadku innego zegara szafowego podano sygnaturę zegarmistrza "Jordan Wiliamson, London” - ibid., nr 327, k. 684v (1786 r.); podobnie jak to uczyniono, opisując kolejny zegar szafowy „Z wagami, z długim perpendykułem i excytarzem”, na którego tarczy umieszczony był napis: „Frantz [!] Voller, London” - ibid., nr 326, k. 68 (1783 r.). Zidentyfikowanie obu zegarmistrzów nie powiodło się, za trud poszukiwań dziękuję kustoszowi Stefanowi S. Mieleszkiewiczowi.

${ }^{27}$ „2 zegary stołowe wiedeńskie” - ibid., nr 327, k. 61 (1785 r.).

${ }^{28}$ Ibid., nr 320, k. 72 (1758 r.).

${ }^{29}$ Ibid., nr 327, k. 740 (1786 r.).

${ }^{30}$ „12 krzeseł krakowskich nieobitych [...], 9 krzeseł obitych starych” - ibid., nr 321, k. 50v (1767 r.).

${ }^{31}$ Ibid., nr 321, k. 50v (1767 r.).

${ }^{32}$ Czesława Betlejewska, Meble gdańskie od XVI do XIX wieku, Warszawa-Gdańsk 2001, s. 79$-91$.

${ }^{33}$ AGAD, Księgi miejskie Starej Warszawy, nr 325, k. 15 (1780 r.). 
Podobnie było u kupca Grzegorza Krzysztofowicza, który był właścicielem dwóch gdańskich szaf. Jak wynika ze wzmianki w inwentarzu, stanowiły one opracowaną analogicznie parę (zostały opisane jako „parzyste”). Były to, podobnie jak w kamienicy Andrychowiczów, meble wycenione najwyżej w całym gospodarstwie domowym ${ }^{34}$. W domu Franciszki Rogalskiej, właścicielki dwóch kamienic przy Rynku Starego Miasta ${ }^{35}$, w garderobie była ustawiona „szafa wielka gdańska snycerską robotą"36. Również Stefan Jaśkiewicz, ławnik Starej Warszawy, w 1763 r. miał gdańską szafę, nie opisano jej jednak dokładniej ${ }^{37}$. W domostwie Łukasza Koziarskiego w końcu XVIII w. taksatorzy dobytku zastali gdańską szafę pokrytą modnym orzechowym fornirem. Mebel był zaopatrzony w dwoje drzwi i dwie szuflady $^{38}$. „Szafa gdańska” u Stefana Makowskiego była przeznaczona na ubrania („do wieszania sukien”). W opisie podano, że została ona wykonana $\mathrm{z}$ drewna sosnowego. Nie wspomniano jednak o opracowaniu powierzchni mebla. Zazwyczaj tego typu tańsze gatunki były barwnie polichromowane, niekiedy na sposób imitujący kosztowniejsze drewno.

\section{MEBLE SIEDZISKOWE}

Kolejne gdańskie wyroby to meble siedziskowe. Zazwyczaj były to krzesła. Najczęściej używano jednorodne zespoły liczące tuzin bądź pół tuzina egzemplarzy ${ }^{39}$. $\mathrm{W}$ niektórych domach zespoły te były jednak już zdekompletowane ${ }^{40}$.

U Grzegorza Gażyńskiego, właściciela kamienicy przy ul. Piwnej, do siedzenia służyło wiele krzeseł, przede wszystkim krakowskich, ale było też pół tuzina mebli gdańskiej proweniencji ${ }^{41}$. Nie można jednak stwierdzić, czy były to tak wówczas modne meble powstające $\mathrm{w}$ warsztatach krześlarzy gdańskich oparte na wzorach angielskich $^{42}$ (il. 2).

${ }^{34} 120$ zł - ibid., nr 327, k. 521v (1786 r.).

${ }^{35}$ Były to kamienice nr 21 i 21 A, numer hipoteczny 43, połączone w początkach XVIII w., gdy należały do rodziny Szubalskich, w końcu XVIII w. były w posiadaniu Rogalskich (zob. Katalog zabytków Sztuki w Polsce, t. 11 (Seria nowa): Warszawa, cz. 1: Stare Miasto, red. Jerzy Zygmunt ŁoZIŃsKi, Andrzej RotTeRmund, Warszawa 1993, s. 248).

${ }^{36}$ AGAD, Księgi miejskie Starej Warszawy, nr 331, k. 58v (1790 r.).

${ }^{37}$ Ibid., nr 321, k. 9v (1763 r.).

${ }^{38}$ Ibid., nr 333, k. 221 (1793 r.).

${ }^{39}$ Np. „6 krzeseł gdańskich” - ibid., nr 321, k. 50 (1767 r.); „12 krzeseł gdańskich” - ibid., nr 325, k. 206 (1783 r.); ibid., Księgi miejskie Warszawa-Ekonomiczne, nr 1223/342, k. 1075v (około 1750 r.).

${ }^{40}$ Np. „7 krzeseł gdańskich” - ibid., Księgi miejskie Starej Warszawy, nr 327, k. 402 (1785 r.); „8 krzeseł gdańskich” - ibid., nr 326, k. 262v (1784 r.); „11 krzeseł gdańskich” - ibid., nr 326, k. 298v (1784 r.).

${ }^{41}$ Ibid., nr 321, k. 50v (1767 r.).

${ }^{42}$ Od 1763 r. działał cech producentów angielskich krzeseł, zob. C. BetLejewsKA, op.cit., s. 186-188 (aneks zawierający spis członków cechu). 
Tapicerkę krzeseł wykładano używaną wówczas chętnie tkaniną trypową ${ }^{43}$ lub adamaszkową, niektóre siedziska były „włosami wysłane”"44. Rzadko występowały krzesła "gdańskie” mające wyplatane trzciną siedziska ${ }^{45}$, zazwyczaj układano na nich dla podniesienia komfortu poduszki.

Niektóre z „gdańskich” krzeseł w domach mieszczan warszawskich mogły być jeszcze meblami barokowymi, ich siedziska były bowiem wybijane skórą ${ }^{46}$ lub złoconym kurdybanem. W domach gdańskich w izbach już niemal nie używano krzeseł ze skórzaną tapicerką, a tego typu sprzęty trafiały tylko do podrzędniejszych pomieszczeń. W Warszawie meble te zachowały stosunkowo wysoką wartość, zwłaszcza jeśli stanowiły komplet. Tuzin takich krzeseł z siedziskami wybitymi skórą miała np. w swym dobytku Magdalena Krenztówna ${ }^{47}$.

W niektórych domach w użyciu były gdańskie krzesła wyłożone kurdybanem $(i 1.3)^{48}$. Dwanaście sztuk tego typu sprzętów, „skórą złotą obitych”, miał w swym domu lekarz Jakub Andrychowicz ${ }^{49}$.

Spora część znajdujących się w stołecznych domach gdańskich mebli siedziskowych zdradzała ślady dłuższego użytkowania ${ }^{50}$, co wskazywałoby na ich starszy rodowód. Na przykład w domu wdowy Zofii Przyłuskiej znajdowały się dwa komplety gdańskich krzeseł. Jeden z nich wybity był wprawdzie „skórą wyzłacaną”, jednak stan zachowania sprzętów budził zastrzeżenia ${ }^{51}$. Nie inaczej było u kupca G. Krzysztofowicza. Sześć należących do niego gdańskich krzeseł było „zażywane”, kolejne pół tuzina określono po prostu jako „stare”

Mniejszą popularnością cieszyły się najwyraźniej gdańskie kanapy, niektóre z nich także były już jakiś czas w użyciu ${ }^{53}$, elementy innych były zniszczone ${ }^{54}$. Trudno orzec, czy były to produkowane w tym czasie nad Motławą kanapy, czy też mamy do czynienia ze starszymi obiektami.

\footnotetext{
${ }^{43}$ W kolorze karmazynowym - AGAD, Księgi miejskie Starej Warszawy, nr 326, k. 262v (1784 r.); w kolorze zielonym - ibid., nr 327, k. 315v (1785 r.). Tryp - tkanina zbliżona do aksamitu, postrzygana (Irena TuRNAU, Stownik ubiorów. Tkaniny, wyroby pozatkackie, skóry, broń i klejnoty oraz barwy znane w Polsce od średniowiecza do początku XIX w., Warszawa 1999, s. 191).

${ }^{44}$ AGAD, Księgi miejskie Starej Warszawy, nr 333, k. 221 (1793 r.). To ostatnie sformułowanie można interpretować jako określenie rodzaju użytej tkaniny - włosienicy, więc materii wełnianej wyrabianej z użyciem włosia końskiego (I. TuRnAU, op.cit., s. 198).

${ }^{45}$ AGAD, Księgi miejskie Starej Warszawy, nr 327, k. 134v (1785 r.).

${ }^{46}$ Ibid., nr 331, k. 78v (1790 r.).

${ }^{47}$ Oszacowany na 48 zł - ibid., nr 333, k. 221 (1793 r.).

${ }^{48}$ Tuzin krzeseł wybitych „skórą pozłocistą” - ibid., Księgi miejskie Warszawa-Ekonomiczne, nr 1223/342, k. 1075v (około 1750 r.); 11 krzeseł „skórą wyzłacaną obitych” - ibid., Księgi miejskie Starej Warszawy, nr 326, k. 298v (1784 r.).

${ }^{49}$ Ibid., nr 327, k. 68v (1785 r.).

${ }^{50} \mathrm{~Np}$. ibid., nr 321, k. 215 (1770 r.).

${ }^{51}$ W spisie mienia został określony jako „zły” - ibid., nr 327, k. 402 (1785 r.).

${ }^{52}$ Ibid., nr 327, k. 520v-521 (1786 r.).

${ }^{53}$ Mebel określono jako „stary” - ibid., nr 327, k. 741 (1786 r.).

${ }^{54}$ Kanapa miała złamaną poręcz, siedzisko było wprawdzie wybijane kurdybanem, ale było już „stare” - ibid., nr 327, k. 134v (1785 r.).
} 
W nielicznych domach w użyciu były stołki wykonane nad Motławą. Antoni Matciński miał nawet tuzin takich mebli „skórą złoconą w kwiaty obitych”, kolejnych dwanaście wyłożonych było czerwoną skórą ${ }^{55}$. Również u Pawła Jaśkiewicza spisujący dobytek zastali „12 stołków gdańskich”, jednak nie wspomniano o rodzaju opracowania siedzisk ${ }^{56}$.

\section{KOMODY I STOŁY}

W nielicznych stołecznych domach znajdowały się komody i stoły „gdańskiej roboty”. Komoda taka była w użyciu u kupca korzennego Piotra Koytkowskiego mieszkającego przy ul. Krakowskie Przedmieście ${ }^{57}$. Nie sposób przesądzić, czy był to jeden z modnych wówczas w Gdańsku mebli o rokokowych formach (il. 4). Wspominany S. Jaśkiewicz miał w domu kilka gdańskich mebli. Oprócz opisanej szafy w jego gospodarstwie domowym był także stolik gdański, zapewne niewielkich rozmiarów $w^{58}$ (il. 5).

\section{KUFRY}

Jednak najwięcej było w domach warszawskich wykonanych w Gdańsku kufrów $^{59}$ (il. 6). Niekiedy w jednym gospodarstwie domowym znajdowało się ich nawet kilka. Na przykład Jerzy Kaulicz miał trzy gdańskie kufry, różnej wielkości - „duży”, „mały” i „mniejszy” ${ }^{60}$. W pierwszej połowie XVIII w. kufry znajdowały się zapewne w dobrym stanie technicznym, ponieważ w inwentarzach brakuje wzmianek o stopniu ich zużycia, natomiast $\mathrm{w}$ drugiej połowie stulecia część $\mathrm{z}$ nich była po prostu zniszczona. Dlatego mnożą się określenia „stare"61, „popsute"62, „dobrze zażywane"63. Niekiedy pozostawiano je nawet „bez taxy”"64 lub kwitowano stwierdzeniem „taxy niewarte”.

Kufry były w całości wykonane $\mathrm{z}$ drewna, obijano je często skórą, np. „świnią morską" ${ }^{\prime}$, „skórą [...] kosmatą" ${ }^{\prime 6}$ lub „czarną" ${ }^{67}$. Wiele pozostawiano jednak bez

${ }_{55}^{55}$ Ibid., Księgi miejskie Warszawa-Ekonomiczne, nr 1223/308, k. 809 (1757 r.).

${ }^{56}$ Ibid., Księgi miejskie Starej Warszawy, nr 321, k. 9v (1763 r.).

${ }^{57}$ Ibid., nr 325, k. 111v (1782 r.).

${ }^{58}$ Ibid., nr 321, k. 9v (1763 r.).

${ }^{59}$ Pogląd ten podziela także B. Maszkowska - „kufry gdańskie wymieniane są prawie w każdym warszawskim inwentarzu mieszczańskim, w spisach rzeczy tak kupców, jak i rzemieślników”, zob. B. MaszKowsKa, op.cit., s. 11.

${ }^{60}$ AGAD, Księgi miejskie Starej Warszawy, nr 327, k. 570v (1785 r.).

${ }^{61}$ Ibid., nr 321, k. 10 (1763 r.); k. 151 (1770 r.); nr 323, k. 51v (1773 r.); nr 327, k. 270v (1785 r.); k. $535 \mathrm{v}(1786 \mathrm{r}$.)

${ }^{62}$ Ibid., nr 327, k. 304 (1785 r.).

${ }^{63}$ Ibid., k. 143 (1785 r.).

${ }^{64}$ Ibid., nr 330, k. 168 (1783 r.).

${ }^{65}$ Ibid., nr 320, k. 233 (1760 r.). Kufry zazwyczaj były obijane skórą foczą lub cielęcą (Marian Rehorowski powołał się na ustalenia Zygmunta Glogera, zob. Marian ReHorowski, Meble gdańskie XVII i XVIII stulecia, Rocznik Gdański, t. 17/18: 1960, s. 120).

${ }^{66}$ AGAD, Księgi miejskie Starej Warszawy, nr 327, k. 740 (1786 r.).

${ }^{67}$ Ibid., k. 522 (1786 r.). 
tego rodzaju wykończenia. Charakterystyczną cechą sprzętu było półokrągłe, wysklepione wieko oraz cylindryczny kształt. Zamykano je na zamek i klucz ${ }^{68}$, „Zamek i antabki” 69 , „kłódki”70 i „skoble” ${ }^{71}$. Zapisy zawarte w inwentarzach przynoszą ograniczone informacje na temat wielkości i kształtu kufrów. Spisujący dobytek wspominali niekiedy, że kufer był np. „mały” ${ }^{72}$, „okrągły”73 lub „półokrągły”74.

\section{WYROBY FAJANSOWE}

Mieszkańcy stolicy używali także "gdańskie” wyroby fajansowe ${ }^{75}$. W kilku gospodarstwach domowych znajdowały się ozdobne garnitury waz, zdobione zapewne w zbliżony sposób jak modne wówczas fajansowe wazy z Delft (il. 7-8). Na przykład wspominany ławnik S. Jaśkiewicz miał „pięć dzbanków gdańskich na szafę" ${ }^{76}$. Kilku innych warszawiaków miało nieopisane dokładniej gdańskie „dzbanuszki”, być może także służące ozdobie wnętrz. U Marianny z Machcińskich Kędzierskiej były one opatrzone inicjałami „CJA"77.

Jednak większość ceramicznych naczyń gdańskich składała się na zastawę stołową i do ciepłych napojów (il. 9-10), w użyciu były „talerze farfurowe gdańskie"78 (najczęściej liczone w tuzinach ${ }^{79}$ ) oraz półmiski. Kupiec G. Krzysztofowicz miał poza gdańskim „niebieskim” półmiskiem również sześć tuzinów gdańskich talerzy ${ }^{80}$.

W domach warszawskich użytkowano także "gdańskie” dzbanki kawowe i filiżanki ${ }^{81}$ oraz dzbanuszki do herbaty ${ }^{82}$. Niektóre $z$ tych fajansowych naczyń znajdowały się w warszawskich domach zapewne od dłuższego czasu, były bowiem obiektami starymi i „zażywanymi”"s.

${ }^{68}$ Ibid., k. 143 (1785 r.).

${ }^{69}$ Ibid., nr 321, k. 61v (1769 r.).

${ }^{70}$ Ibid., nr 327, k. 304 (1785 r.).

${ }^{71}$ Ibid., nr 324, k. 312v (1781 r.).

${ }^{72}$ Ibid., nr 323, k. 21 (1773 r.).

${ }^{73}$ Ibid., nr 326, k. 9v (1770 r.); nr 327, k. 270v (1785 r.).

${ }^{74}$ Ibid., nr 327, k. 687v (1786 r.).

${ }^{75} \mathrm{Na}$ temat ośrodków produkcyjnych działających w Gdańsku i wokół miasta zob. Hans Friedrich Secker, Die alte Töpferkunst Danzigs und seiner Nachbarstädte, Der Cicerone, Jg. 7: 1915, H. 13/14, s. 241-258; Elżbieta Kilarska, Fajanse $z$ Delft $w$ dawnym Gdańsku, Gdańsk 2003, s. 147-152 (tam o pomorskiej ceramice wzorowanej na wyrobach z Delft).

${ }^{76}$ AGAD, Księgi miejskie Starej Warszawy, nr 321, k. 9v (1763 r.).

${ }^{77}$ Ibid., Księgi miejskie Warszawa-Ekonomiczne, 1223/317, s. 864v (1768 r.).

${ }^{78}$ Ibid., Księgi miejskie Starej Warszawy, nr 321, k. 61v (1767 r.).

${ }^{79}$ Ibid., Księgi miejskie Warszawa-Ekonomiczne, nr 1223/308, k. 810 (1757 r.).

${ }^{80}$ Ibid., Księgi miejskie Starej Warszawy, nr 327, k. 522v (1786 r.).

${ }^{81}$ Ibid., nr 321, k. 9v (1763 r.); Księgi miejskie Warszawa-Ekonomiczne 1223/317, k. 864v (1768 r.).

${ }^{82}$ Ibid., Księgi miejskie Starej Warszawy, nr 327, k. 522v (1786 r.).

${ }^{83}$ Ibid. 


\section{WYROBY CYNOWE}

W domach warszawskich powszechnie korzystano nadal z cynowych naczyń stołowych, przede wszystkim z cyny koronnej oraz angielskiej. Ta ostatnia należała do wyrobów cennych, przewyższała wartością o 100\% wyroby „koronne” ${ }^{\text {. Jedy- }}$ nie wyjątkowo posługiwano się naczyniami cynowymi gdańskiej produkcji. Większy zespół gdańskich naczyń znajdował się np. na wyposażeniu domu Franciszka Barszczewicza, obejmował on talerze, misy i półmiski ${ }^{85}$.

\section{TKANINY OBICIOWE}

W Warszawie tkaniny pokrywające ściany były odrębnie wyceniane, dzięki temu stołeczne źródła pozwalają odnotować ich występowanie, a niekiedy dają możliwość określenia proweniencji tych wyrobów. Wśród obić tekstylnych pojawiały się też tkaniny gdańskie, choć skala użytkowania ich w domach warszawskich, podobnie jak to było w przypadku wspominanych sprzętów domowych, jest marginalna.

Kilka rodzajów gdańskich tkanin obiciowych znajdowało się w domu Wojciecha Banczakiewicza, kupca i mieszczanina warszawskiego. Fakt ten nie wywołuje zdziwienia, gdyż jego brat mieszkał w Gdańsku, gdzie uprawiał tę samą profesję. W należącej do Wojciecha starej kamienicy przy Podwalu spisujący dobytek odnotowali „obicia ordynaryjnego, gdańskiego 65 brytów” oraz „obicia w narożnej izbie gdańskiego 44 łokci”. Ściany w nowej kamienicy należącej także do kupca W. Banczakiewicza zdobiły, oprócz innych tkanin, np. saskich „na żółtym gruncie lakierowanych”, także „obicia w słupy gdańskie” i tej samej proweniencji „obicia na niebieskim gruncie" 86 .

W innych domach tylko sporadycznie występowały gdańskie tkaniny ścienne, niektóre z nich były określane jako „ordynaryjne”. Niestety, na temat użytych wzorów i gamy barwnej źródła milczą.

Fakt użytkowania do wystroju wnętrz obić ściennych gdańskiej proweniencji jest szczególnie interesujący, ponieważ w dotychczasowych badaniach nie wiązano wytwórczego ośrodka nad Motławą z tego rodzaju produkcją. Źródłowe materiały gdańskie pozwalają jedynie na uzyskanie informacji mających przyczynkarski charakter. Wiadomo wprawdzie, że w drugiej połowie XVIII w. przy ulicy Kotwiczników (Ankerschmiedegasse) działała drukarnia tkanin przeznaczonych na obicia ścienne ${ }^{87}$, jednak nie wiemy nic bliższego ani o ich kolorystyce, ani o sto-

${ }^{84}$ Stanisław Siegel, Ceny w Warszawie w latach 1701-1815, Lwów 1936, s. 114.

${ }^{85}$ AGAD, Księgi miejskie Starej Warszawy, nr 331, k. 49 (1790 r.). Na temat gdańskich wyrobów cynowych zob. Barbara Tucho£Ka-WŁodarska, Cyna od XV do XIX wieku. Katalog stałej wystawy ze zbiorów Muzeum Narodowego w Gdańsku, Gdańsk 1992.

${ }^{86}$ AGAD, Księgi miejskie Starej Warszawy, k. 76 (1758 r.). Fragmenty inwentarza przytacza: B. MaszKowsKa, op.cit., s. 77, przyp. 20.

${ }^{87}$ Działający tam drukarz oferował ,einige gedruckte Wachstücher zu Stubenbeschläge”, zob. Wöchentliche Danziger Anzeigen und dienliche Nachrichten, 1763, Nr. 19, s. 95; 1781, Nr. 23, s. 270. 
sowanych wzorach. Zapewne produkowała ona obicia na potrzeby miejscowego rynku, jednak charakter gdańskich źródeł nie pozwala na wskazanie wykorzystania tego rodzaju obićs ${ }^{8}$.

\section{BIELIZNA STOŁOWA I RĘCZNIKI}

Stołeczni mieszczanie używali gdańską bieliznę stołową. Naturalnie w ich domach występowały również wyroby holenderskie, krakowskie czy też śląskie ${ }^{89}$. Gdańskich obrusów $w^{90}$ i serwet ${ }^{91}$ nie było zresztą wiele. Większość tej bielizny była mocno używana, pocerowana i stara ${ }^{92}$. Wskażmy dla przykładu gospodarstwo domowe wspominanego P. Koytkowskiego. W użyciu było tam kilka gdańskich obrusów (wśród nich cztery „dobrze używane”, jeden „cerowany”) oraz dwa tuziny serwet gdańskich, „niektóre [z nich również były] cerowane”. Jeszcze mniej liczne były gdańskie ręczniki ${ }^{93}$. Dwa tuziny takich ręczników miał lekarz Jakub Anrychowicz $^{94}$, a jedynie 5 sztuk kupiec Mikołaj Jędrzejowicz ${ }^{95}$.

${ }^{88}$ Wyceny domostw sporządzane przez starszych cechów murarzy i cieśli domowych nie uwzględniały rodzaju opracowania ścian. Na temat tego źródła w badaniach nad kulturą zamieszkiwania zob. Edmund KIzIK, Cechowe oględziny budynków mieszkalnych w Gdańsku w XVII-XVIII wieku, [in:] Studia i materiały do dziejów domu gdańskiego, cz. 1, red. Edmund Kızıк, Gdańsk 2009, s. 145-161. Także anonse prasowe o sprzedaży i wynajmie mieszkań poza faktem odnotowywania tkanin ściennych jedynie wyjątkowo uwzględniały ich, zazwyczaj obcą, proweniencję. Na temat tego źródła zob. Ewa BARYlewsKa-SzymańsKa, Wojciech SzYMAŃsKi, Anonse prasowe w „Danziger Erfahrungen" - źródło do badań nad budownictwem mieszkaniowym osiemnastowiecznego Gdańska, [in:] ibid., s. 163-185.

${ }^{89}$ Bielizna stołowa holenderska: np. „serweta do kawy olenderska” - AGAD, Księgi miejskie Starej Warszawy, nr 321, k. 188v (1770 r.); „5 serwet olenderskich do kawy, [...] 20 serwet różnego gatunku holenderskich, mocna cerowanych, [...] 9 obrusów różnego gatunku Hollenderskich dużo cerowanych” - ibid., nr 325, k. 9 (1780 r.); „2 obrusy holenderskie po 5 łokci dług[ości], [...] 2 [obrusy] holenderskie cerowane" - ibid, nr 325, k. 109-109v (1782 r.). Bielizna stołowa krakowska: „5 obrusów krakowskich [...] 12 serwet krakowskich różnego gatunku używanych całych, [...] 8 ręczników krakowskich” - ibid., nr 325, k. 9-9 v (1780 r.); „7 obrusków krakowskich używanych, [...] 2 obruski krakowskie małe, [...] 12 serwet krakowskich" - ibid, nr 325, k. 109-109 v (1782 r.); „10 obrusów krakowskich, 3 tuziny serwet ditto” - ibid., Księgi miejskie Warszawa-Ekonomiczne, nr 1223/342, k. 1073v (około 1750 r.). Bielizna stołowa śląska: różnej wielkości obrusy, kilka tuzinów serwet i ręczników - ibid., Księgi miejskie Warszawa-Ekonomiczne, nr 1223/308, k. 808-808v (1757 r.); nr 1223/342, k. 1073 (około 1750 r.).

${ }^{90}$ Np. ibid., Księgi miejskie Warszawa-Ekonomiczne, nr 1223/342, k. 1073v (około 1750 r.); Księgi miejskie Starej Warszawy, nr 326, k. 11, 26 (1770 r.).

${ }_{91}^{1}$ Np. ibid., Księgi miejskie Starej Warszawy, nr 325, k. 9 (1780 r.); nr 325, k. 109v (około 1782 r.).

${ }^{92}$ Np. Ibid., Księgi miejskie Warszawa-Ekonomiczne, nr 1223/308, k. 808v (1757 r.); Księgi miejskie Starej Warszawy, nr 325, k. 109v (około 1782 r.).

${ }^{93} \mathrm{~Np}$. ibid., nr 1223/342, k. 1073v (około 1750 r.).

${ }^{94}$ Ibid., Księgi miejskie Starej Warszawy, nr 327, k. 66 (1785 r.).

${ }^{95}$ Ibid., Księgi miejskie Warszawa-Ekonomiczne, nr 1223/342, s. 1073v (około 1750 r.). 


\section{PODSUMOWANIE}

Gdańskich wyrobów w domach mieszczan warszawskich było w drugiej połowie XVIII stulecia niewiele, jednak warto zjawisko to odnotować. Hanna Szwankowska przyjęła, że większość sprzętów gdańskich w stołecznych domach, podobnie zresztą jak holenderskich, pochodziła jeszcze z XVII i początków XVIII w. ${ }^{96}$ W odniesieniu do pewnych sprzętów, choćby niektórych krzeseł, stwierdzenie to wydaje się słuszne, zważywszy na duży stopień ich zużycia. Zapewne, wnosząc z oszczędnych opisów, także szafy były sprzętami pochodzącymi z początków XVIII w. Trudno natomiast jednoznacznie wyrokować na temat pozostałych typów mebli (kufrów, komód, kanap, stolików) oraz wyrobów cynowych, fajansowych, obić ściennych czy też bielizny pościelowej. Ta ostatnia wprawdzie także często opisywana była jako stara czy też pocerowana, ale tego typu rzeczy zużywają się szczególnie szybko i już po kilku latach noszą nieodwracalne ślady czasu. Być może więc na rynek warszawski trafiały nadal niektóre gdańskie wyroby także w drugiej połowie XVIII stulecia. Kontakty między kupiectwem obu miast były przecież ożywione.

Warto zwrócić uwagę na kilka typów przedmiotów gdańskiej proweniencji, które w stołecznych domach mieszczańskich nie zostały odnotowane. Nie natrafiłam w objętych kwerendą źródłach na gdańskie piece lub zastosowanie gdańskich kafli piecowych, a były one także nad Motławą zamawiane i transportowane w głąb Rzeczypospolitej ${ }^{97}$.

W stołecznych domostwach brakuje także w przebadanym przeze mnie materiale gdańskich zegarów ${ }^{98}$, a przecież również one miały dobrą renomę daleko poza granicami miasta, jednak jako przedmioty luksusowe zyskiwały odbiorców przede wszystkim w środowisku szlacheckim i magnackim.

Podobnie rzecz ma się z gdańskimi wyrobami złotniczymi. Srebra stołowe także należały do wyrobów luksusowych ${ }^{99}$, jednak elementy srebrnej zastawy stołowej dość często odnotowywane były w analizowanych przeze mnie inwentarzach. Zapewne były to jednak wyroby stołecznych rzemieślników, ponieważ w zapisach inwentarzowych nie ma jakichkolwiek wskazówek na temat proweniencji wyrobów.

Do jeszcze jednej kwestii w kontekście omawianych tu zagadnień należy się odnieść: czy wyroby opisywane jako "gdańskie” rzeczywiście powstały nad Motławą. Kwestia ta musi pozostać otwarta, należy jednak zauważyć, że przynajmniej

${ }^{96}$ H. SzwankowsKa, op.cit, s. 32.

${ }^{97}$ Kwestie te porusza: Barbara Pospieszna, Piece i kafle gdańskie w XVIII wieku, [in:] Średniowieczne $i$ nowożytne kafle. Regionalizmy, podobieństwa, różnice, red. Maria DĄBRowsKA, Halina KARWOWsKa, Białystok 2007, s. 161-166.

${ }^{98} \mathrm{Na}$ temat miejscowej produkcji zegarmistrzowskiej zob. Zuzanna PrószyŃsKa, Słownik zegarmistrzów gdańskich, [in:] Zegary gdańskie. Wystawa zorganizowana w 35-lecie Muzeum Historycznego Miasta Gdańska, red. Zuzanna Prószyńska [i in.], Gdańsk 2005, s. 131-165.

${ }^{99}$ Złotnictwo gdańskie ma bogatą literaturę, w tym miejscu można wskazać np. pracę: Barbara TuchoŁka-WŁodarska, Złotnictwo od XIV do XX wieku. Katalog zbiorów Muzeum Narodowego w Gdańsku, Gdańsk 2005. 
w odniesieniu do mebli możemy mieć do czynienia także w wyrobami powstałymi na północy, w ośrodkach nieodległych od Gdańska i utrzymanymi w typie sprzętów gdańskich ${ }^{100}$.

dr Ewa Barylewska-Szymańska

Instytut Historii PAN

e-mail: e.szymanska@ihpan.edu.pl

${ }^{100} \mathrm{Na}$ zagadnienia te zwracali już uwagę: Tadeusz KruszyŃski, Sprzęty gdańskie i tak zwane gdańskie, Rzeczy Piękne, R. 8: 1929, nr 2, s. 53-56; B. Maszkowska, op.cit., s. 10.

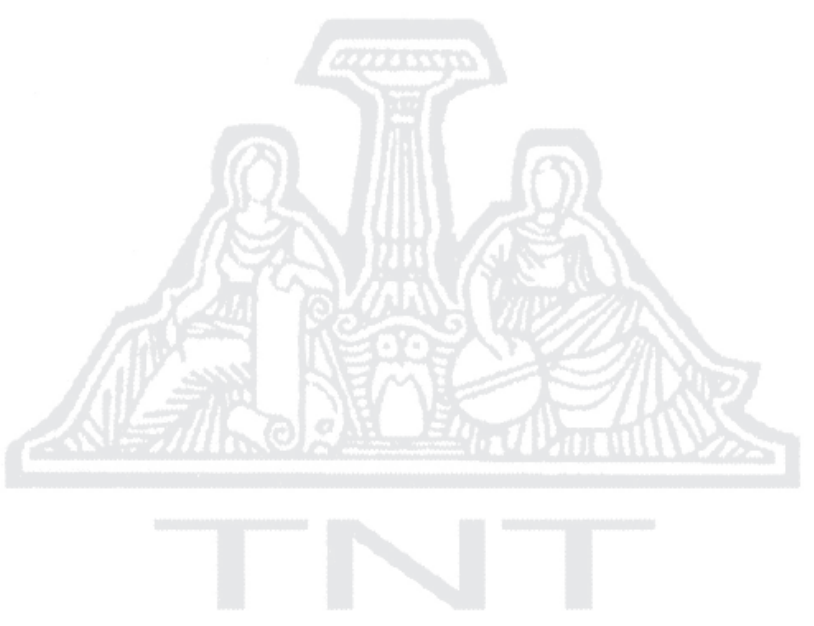




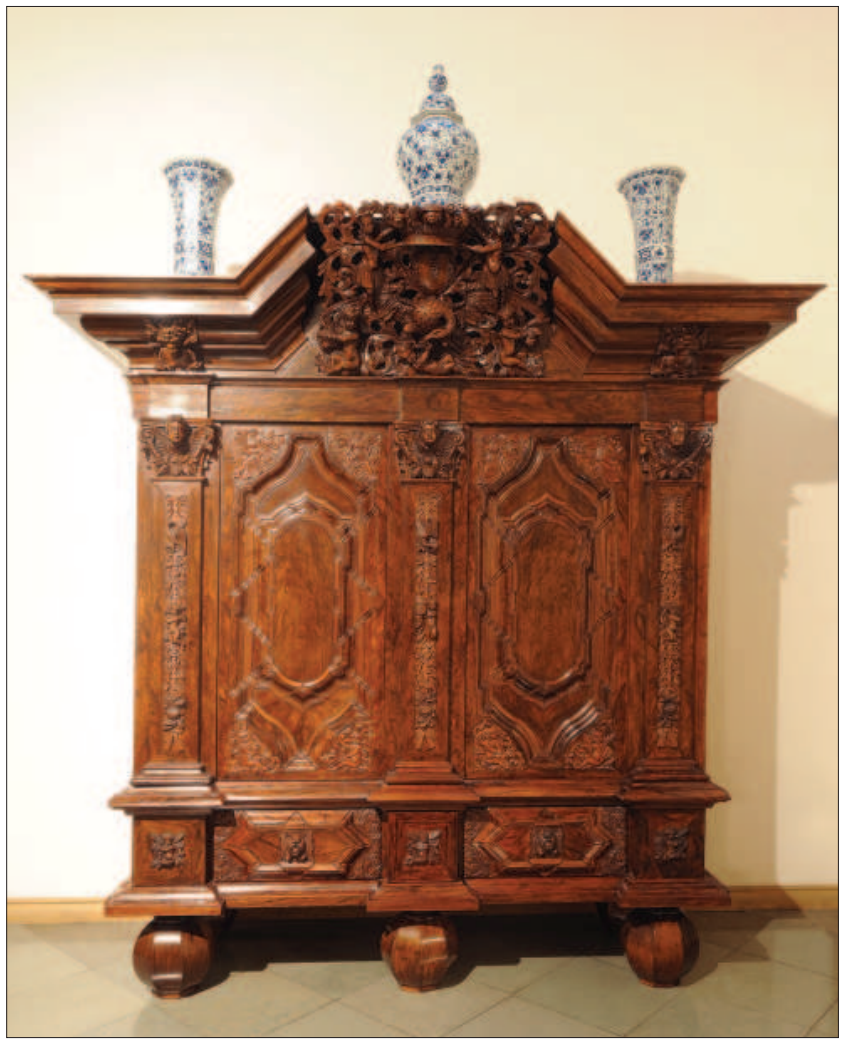

1. Szafa gdańska, druga ćwierć XVIII w.

(Dom Uphagena, oddział Muzeum Historycznego Miasta Gdańska)

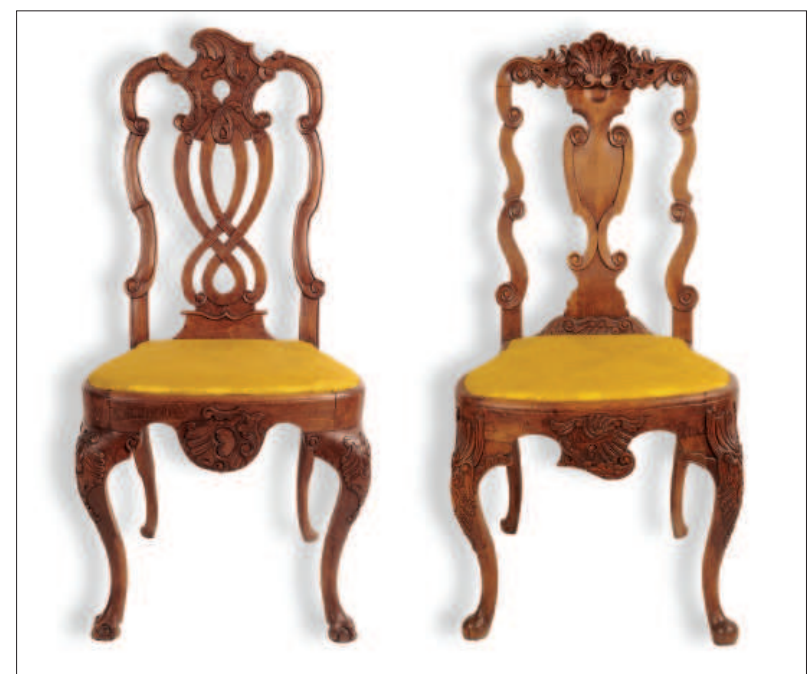

2. Dwa krzesła w typie mebli angielskich, trzecia ćwierć XVIII w. (Dom Uphagena, oddział Muzeum Historycznego Miasta Gdańska)

WWw.zapiskihistoryczne.pl 


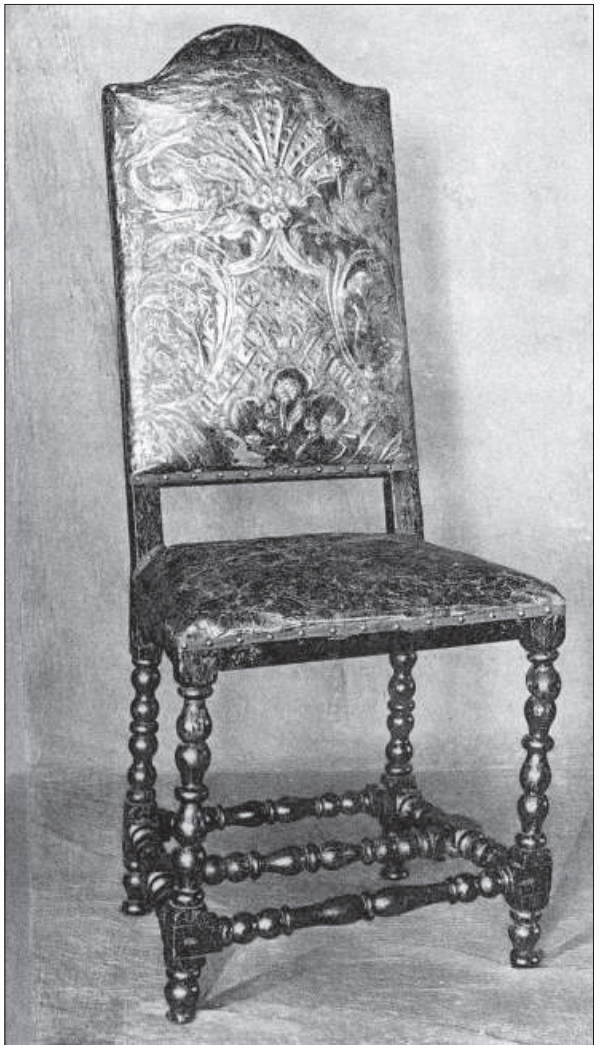

3. Krzesło barokowe z kurdybanem, pierwsza połowa XVIII w. (według: Friedrich Basner, Heinrich Wichmann, Kunst und Kunsthandwerk im Hause Basner, Danzig 1925, tab. 67b)

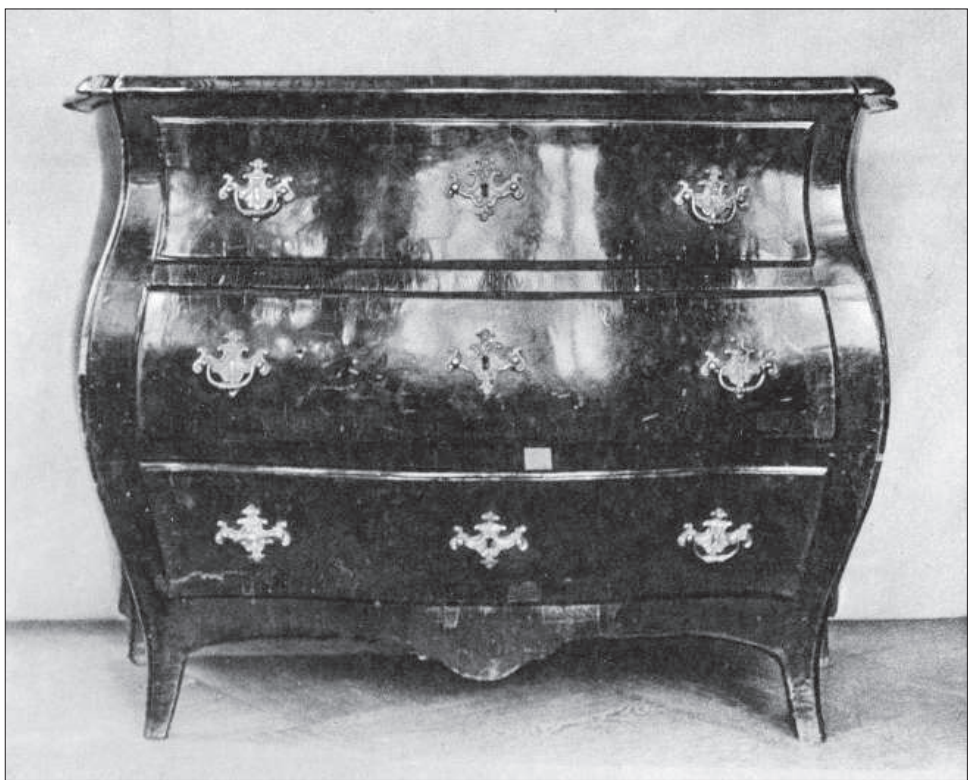

4. Komoda, trzecia ćwierć XVIII wieku (według: Friedrich BASNer, Heinrich Wichmann, Kunst und Kunsthandwerk im Hause Basner, Danzig 1925, tab. 48a) 


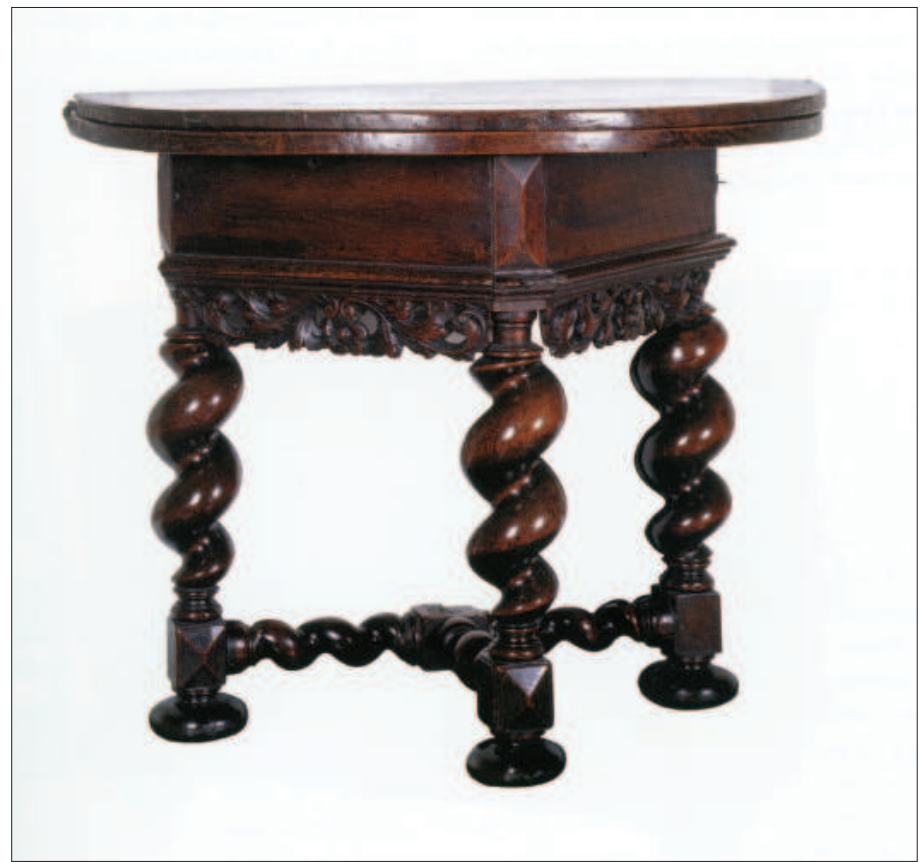

5. Barokowy stól, początek XVIII w. (według: Klejnot w koronie Rzeczypospolitej. Sztuka zdobnicza Prus Królewskich, t. 2: Katalog. Muzeum Narodowe w Gdańsku, red. Czesława BetLejewska, Gdańsk 2006, s. 307)

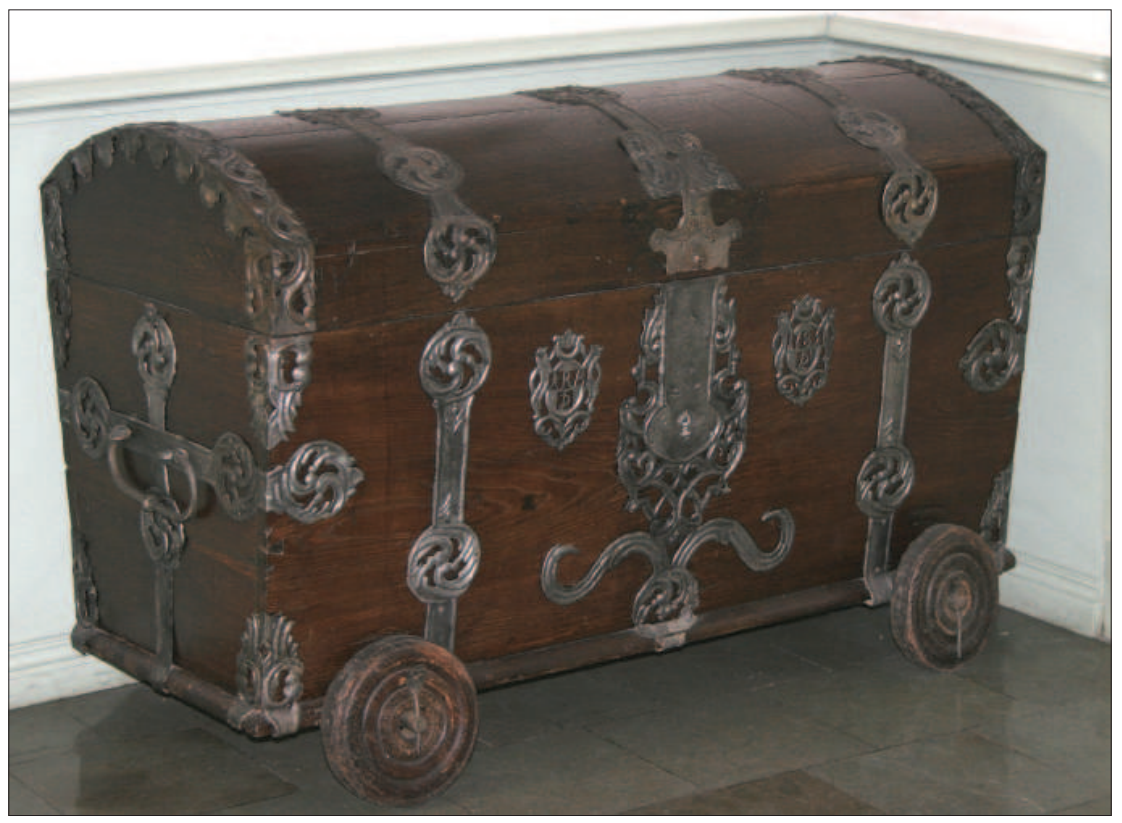

6. Skrzynia kufrowa, $1783 \mathrm{r}$.

(Dom Uphagena, oddział Muzeum Historycznego Miasta Gdańska)

WWw.zapiskihistoryczne.pl 


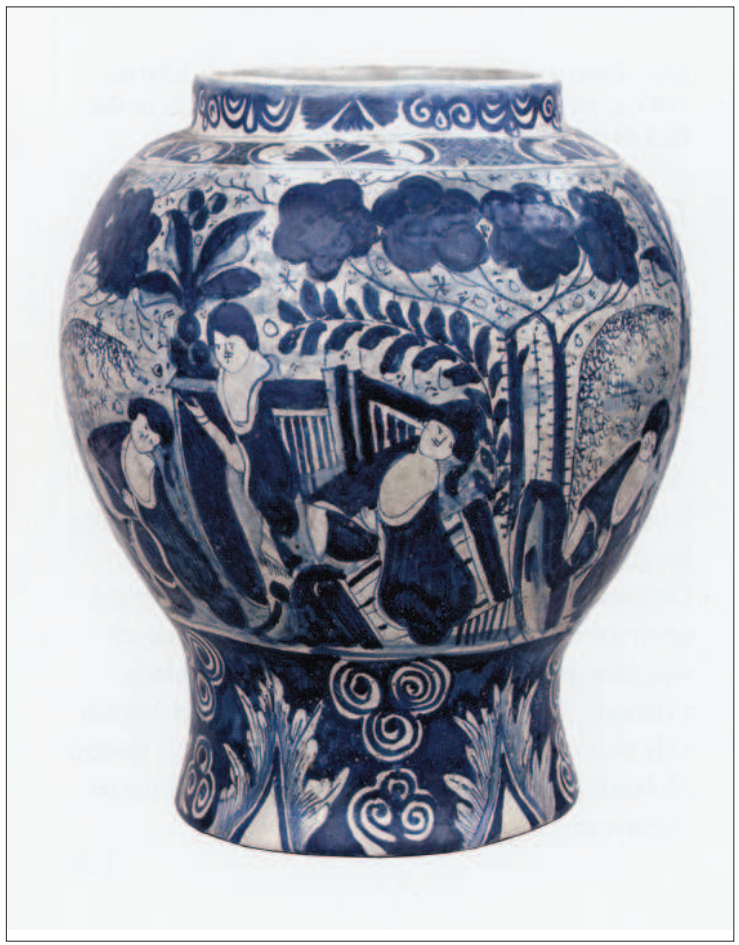

7. Waza prawdopodobnie z garnituru waz, około $1740 \mathrm{r}$. (według: Klejnot $w$ koronie Rzeczypospolitej. Sztuka zdobnicza Prus Królewskich, t. 2: Katalog. Muzeum Narodowe w Gdańsku, red. Czesława BetLejewsKA,

Gdańsk 2006, s. 500)

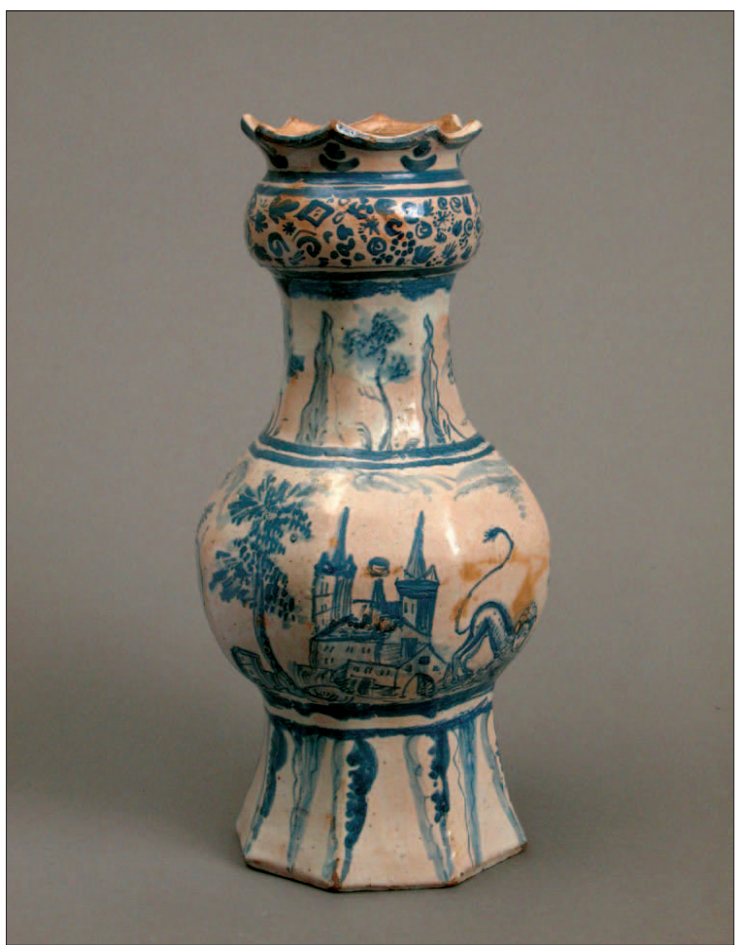

8. Wazon fajansowy, pierwsza połowa XVIII w. (Muzeum Zamkowe w Malborku, fot. Lech Okoński)

WW w. zapiskih is toryczne.pl 


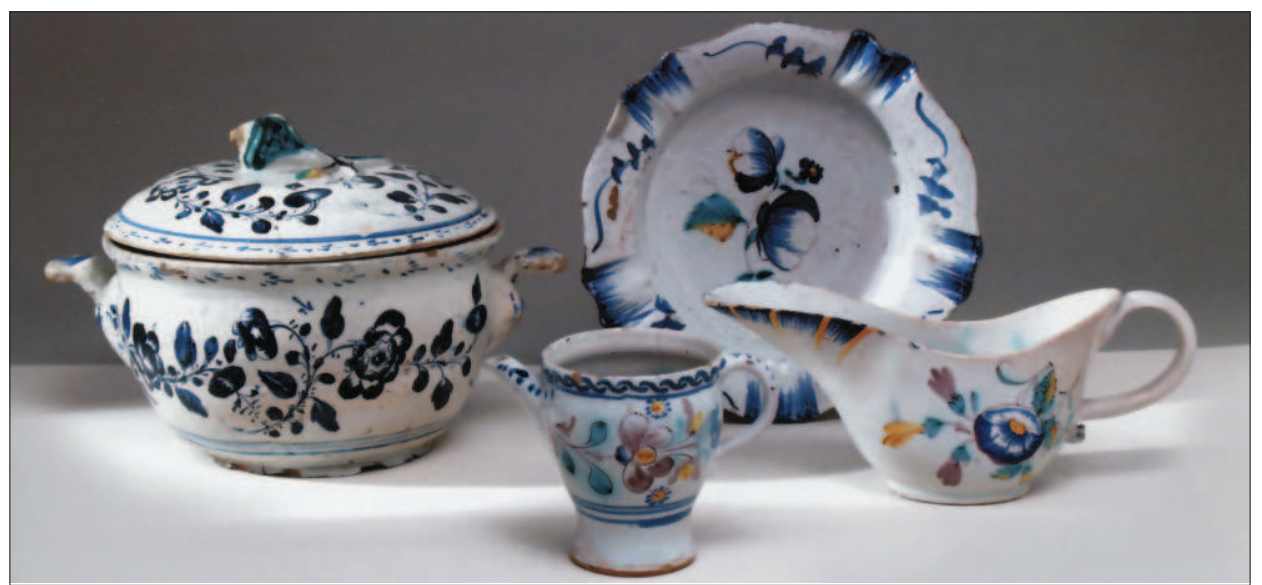

9. Gdański fajans stołowy, czwarta ćwierć XVIII w. (według: Klejnot w koronie Rzeczypospolitej. Sztuka zdobnicza Prus Królewskich, t. 2: Katalog. Muzeum Narodowe w Gdańsku, red. Czesława Betlejewska, Gdańsk 2006, s. 505)

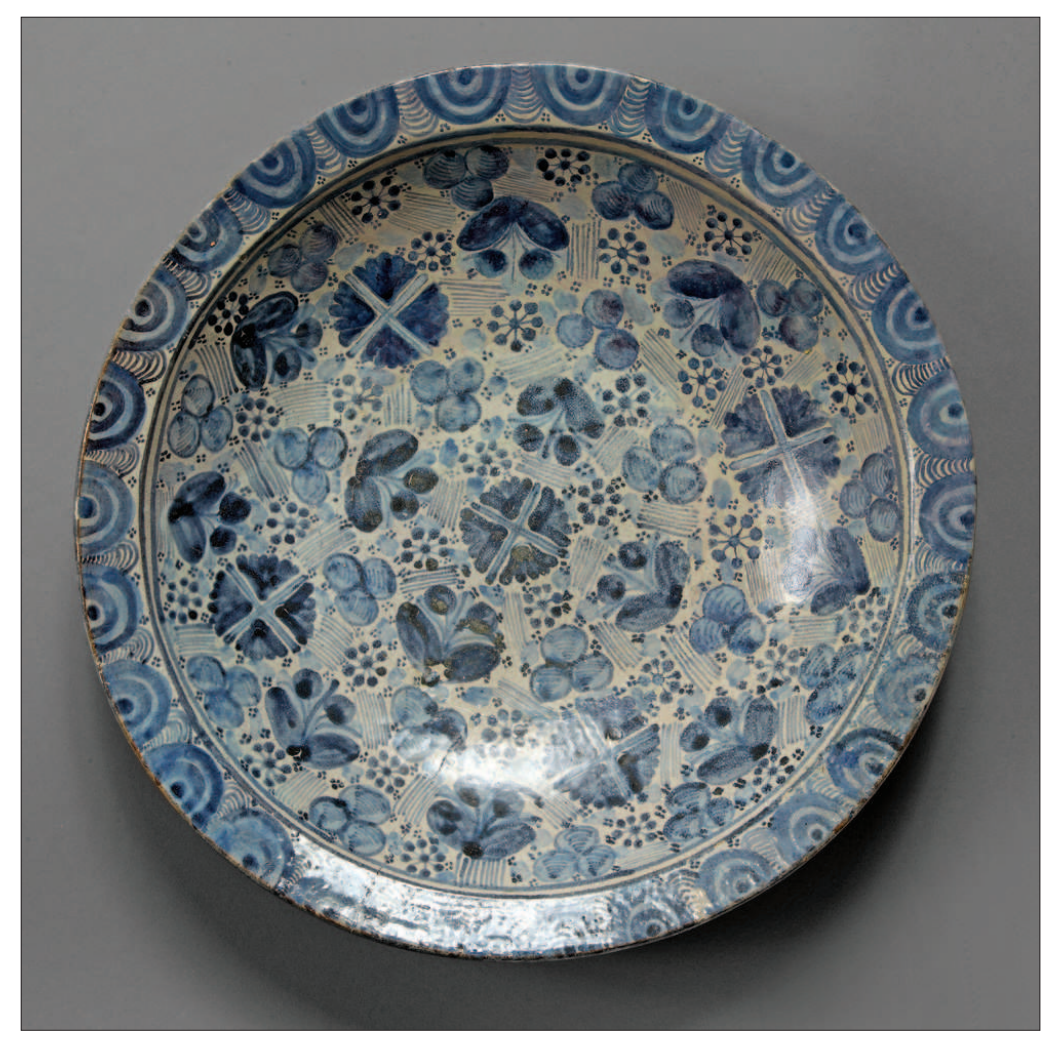

10. Talerz dekoracyjny, około 1725 r. (Muzeum Zamkowe w Malborku, fot. Lech Okoński) 


\section{„DANZIGER KRAM” IN WARSCHAUER BÜRGERHÄUSERN IN DER ZWEITEN HÄLFTE DES 18. JAHRHUNDERTS}

\section{Zusammenfassung}

Schlüsselwörter: Möbel, Gefäße, Fayence, Zinn, Stoff, Danzig, Bürgertum, Warschau, materielle Kultur

In Forschungen zum polnischen Handwerk und der materiellen Kultur hat man seit langem auf Danzig als den Ort hingewiesen, an dem man sowohl importierte Waren, in der Regel Luxuswaren, wie auch Gegenstände kaufen konnte, die in den Werkstätten der städtischen Handwerker hergestellt waren. Auf dem Danziger Markt deckten sich im 18. Jahrhundert die polnische Szlachta, die Geistlichkeit und die Magnaten ein. Auch das Warschauer Bürgertum war Abnehmer von Danziger Erzeugnissen. Dieser Umstand ist bereits zum Gegenstand der Forschung geworden, denn zumindest Bożenna Maszkowska und Hanna Szwankowska haben diese Frage berührt. Zwar gab es in den Warschauer Bürgerhäusern in der zweiten Hälfte des 18. Jahrhunderts nicht viele Danziger Erzeugnisse, doch lohnt es sich das Phänomen wahrzunehmen. Wir finden in ihnen Schränke, Sitzmöbel, Kommoden und Tische. Am häufigsten fanden sich in Warschauer Häusern Truhen, die in Danzig angefertigt worden waren. Die Liste der Gegenstände wird vervollständigt durch Arbeiten in Fayence und Zinn, Bezugsstoffe, Tischzeug und Handtücher. Offen bleibt die Frage, ob die Erzeugnisse, die als „Danziger“ bezeichnet wurden, tatsächlich an der Mottlau entstanden waren oder ob sie im Norden an Orten in der Nähe von Danzig hergestellt und im Stil von Danziger Ware gehalten wurden.

\section{“GDANSK ITEMS” IN THE HOUSES OF WARSAW BURGHERS IN THE SECOND HALF OF THE $18^{\mathrm{TH}}$ CENTURY}

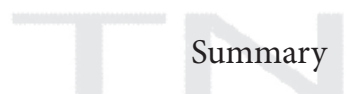

Key words: furniture, dishes, faience, tin, fabrics, Gdansk, burghers, Warsaw, material culture

As proven by research on Polish craft and material culture, Gdansk has for a long time been considered as a destination for both imported luxurious goods and products made in local craftsmen's workshops. The Gdansk market of the $18^{\text {th }}$ century responded to the needs of the Polish noblemen, clergy and magnates. Burghers from Warsaw also purchased goods sold in Gdansk. This issue has been touched upon in earlier research by Bożenna Maszkowska and Hanna Szwankowska. There were few Gdansk products in the houses of Warsaw burghers in the second half of the $18^{\text {th }}$ century; however, the phenomenon is worth mentioning. In the houses of Warsaw burghers wardrobes, seating furniture, cabinets andtables could be found. Nevertheless, the most common goods found in Warsaw homes were boxes manufactured in Gdansk. The list also includes faience and tin products, furnishing fabrics, table cloths and towels. Yet, it is uncertain whether the goods described here were manufactured in Gdansk, or perhaps they were made in the north of Poland in smaller centres near Gdansk, which copied the Gdansk manufacturing style.

$$
\text { w w w. zapis ki historyczne.pl }
$$

